\title{
A New Isoflavone with Antifungal Activity from Immature Fruits of Lupinus luteus
}

\author{
Hiroshi Fukur, Hiroshi Egawa,* Koichi Koshimizu \\ and Tetsuo Mitsui \\ Department of Food Science and Technology, *Pesticide Research Institute, \\ Faculty of Agriculture, Kyoto University, Kyoto 606
}

Received September 16, 1972

\begin{abstract}
A new isoflavone having antifungal activity was isolated from immature fruits of Lupinus luteus (Leguminosae), and named luteone. The structure was shown to be 5,7,2',4'-tetrahydroxy-6-(3,3-dimethylallyl)-isoflavone by degradative and spectroscopic studies.
\end{abstract}

Previously, we had isolated three new $\mathrm{C}_{20^{-}}$ gibberellins, $\mathrm{A}_{18},{ }^{1,} \mathrm{~A}_{23},{ }^{2}$, and $\mathrm{A}_{28},{ }^{3,}$ abscisic acid $^{4}$ and its glucosyl ester ${ }^{5 /}$ from the methanol extract of immature fruits of Lupinus luteus (Leguminosae). In the course of a continuing search for other biologically active substances from higher plants, we found that the benzene extract obtained from the titled fruits showed significant inhibitory activity against the conidia of Cochliobolus miyabeanus (Helminthosporium oryzae). An active component isolated was a new isoflavone, and named luteone. This paper presents the structure and biological activities of luteone.

The methanol extract obtained from immature fruits $(60 \mathrm{~kg})$ of Lupinus luteus was concentrated under reduced pressure. The aqueous concentrate, after adjustment to pH 3 with $6 \mathrm{~N} \mathrm{HCl}$, was extracted with benzene. The benzene extract was purified by chromatography successively over silicic acid (benzeneethyl acetate) and over Florisil (benzeneethyl acetate), affording a crude active material. Recrystallization from methanol-water gave luteone as pale yellow plates $(550 \mathrm{mg}), \mathrm{mp}$ $225 \sim 227^{\circ} \mathrm{C}$.

Luteone, from elemental analysis and mass spectrometric measurement, had the molecular formula $\mathrm{C}_{20} \mathrm{H}_{18} \mathrm{O}_{6}$. The UV spectrum showed absorption maxima at 266 and $290 \mathrm{sh} . \mathrm{m} \mu$ ( 28300 and 14100), and the IR spectrum the absorption at $1655 \mathrm{~cm}^{-1}$ assignable to carbonyl function. These spectroscopic properties immediately suggested that luteone had an isoflavone skeleton. ${ }^{6 \sim s \text { s }}$

Treatment of luteone with dimethyl sulfate in acetone in the presence of anhydrous potassium carbonate gave a trimethyl ether (Ib), which was also prepared by treatment of luteone with ethereal diazomethane. The PMR spectrum $\left(\mathrm{CCl}_{4}\right)$ of the methyl ether (Ib) showed signals attributable to aromatic protons at $\delta 6.29(1 \mathrm{H}, \mathrm{s}),. \quad \delta 6.35 \sim 7.22(3 \mathrm{H}$, ABX system) and $\delta 7.72(1 \mathrm{H}, \mathrm{s}$. $)$. The last characteristic low-field singlet was assignable to an isoffavonoid $\mathrm{C}_{2}-\mathrm{H}^{9}{ }^{9}$ Signals at 01.65 and $1.78(3 \mathrm{H}$ each, br.s.), $03.28(2 \mathrm{H}$, br.d., $J=8 \mathrm{~Hz}$ ) and $\delta 5.15$ (1H,br.t., $J=8 \mathrm{~Hz}$ ) indicated the presence of a 3,3-dimethylallyl group. In addition, the spectrum showed the signals assignable to three methoxy-groups $(03.78,3.80$ and $3.89,3 \mathrm{H}$ each, s.) and one strongly chelated hydroxy-group $(\delta 12.91,1 \mathrm{H}$, s.), which was attributable to $\mathrm{C}_{5}-\mathrm{OH}$ and failed to undergo methylation by the reagents described above. Acetylation of luteone with acetic anhydride-pyridine under reflux gave a tetraacetate (Ic), whose PMR spectrum exhibited the signals due to four acetoxy-groups at $82.04,2.18,2.22$ and 2.31 . These data indicated that luteone was a tetrahydroxyisoflavone having a 3,3-dimethylallyl substituent.

In the UV spectra (Table I) of luteone, the 
Table I. The UV Absorption Maxima* (m $\mu$ ) of Luteone

\begin{tabular}{|c|c|c|c|c|c|c|}
\hline & $\mathrm{MeOH}$ & $\mathrm{NaOAc} c^{a)}$ & $\left.\mathrm{AlCl}_{3}{ }^{b}\right)$ & $\mathrm{AlCl}_{3} / \mathrm{HCl}^{(j)}$ & $\mathrm{NaOAc} c^{d s}$ & $\mathrm{NaOAc} / \mathrm{H}_{3} \mathrm{BO}_{3}{ }^{e}$ \\
\hline & 266 & 223 & 276 & 277 & 271 & 267 \\
\hline Luteone & 290 sh. & $\begin{array}{l}279 \\
337\end{array}$ & $316 \mathrm{sh}$. & $313 \mathrm{sh}$. & 340 sh. & 290 sh. \\
\hline
\end{tabular}

* All the spectra were obtained according to the procedure presented by T. J. Marbry et al. (cf. ref. 10).

a) The $\mathrm{NaOMe}$ spectrum was measured immediately after the addition of three drops of $2.5 \% \mathrm{NaOMe}$ in methanol to a methanolic solution of luteone.

b) The $\mathrm{AlCl}_{3}$ spectrum was measured immediately after the addition of six drops of $5 \% \mathrm{AlCl}_{3}$ in methanol to a methanolic solution of luteone.

c) The $\mathrm{AlCl}_{3} / \mathrm{HCl}$ spectrum was recorded immediately after the addition of three drops of $2 \mathrm{~N} \mathrm{HCl}$ to the cuvette containing the $\mathrm{AlCl}_{3}$ (from step b).

d) The NaOAc spectrum was determined immediately after the addition of excess anhyd. NaOAc (powder) to a methanolic solution of luteone.

e) The $\mathrm{NaOAc} / \mathrm{H}_{3} \mathrm{BO}_{3}$ spectrum was determined immediately after the addition of sufficient anhyd. $\mathrm{H}_{3} \mathrm{BO}_{3}$ to the cuvette which contained the NaOAc (from step d).



$\underbrace{O R}_{O}$

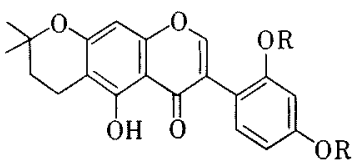

IIa $: \mathrm{R}=\mathrm{H}(\alpha$-isoluteone $)$ $\mathrm{IIa}: \mathrm{R}=\mathrm{Me}$

IIIa $: \mathrm{R}=\mathrm{H}(\beta$-isoluteone $)$ IIIb : $\mathrm{R}=\mathrm{Me}$

$\mathrm{AlCl}_{3}$ spectrum did not exhibit a bathochromic shift with respect to the $\mathrm{AlCl}_{3} / \mathrm{HCl}$ spectrum, and a bathochromic shift was not detectable also on the addition of $\mathrm{NaOAc} / \mathrm{H}_{3} \mathrm{BO}_{3}$ to a methanolic solution of luteone. These suggested that luteone neither contained $o$ dihydroxyl groups at $\mathrm{C}-6,7$ nor at $\mathrm{C}-7,8{ }^{10}{ }^{10}$ On the other hand, a bathochromic shift $(10 \mathrm{~m} \mu)$ was observed on the addition of $\mathrm{AlCl}_{3}$ to the methanolic solution, and also $\mathrm{NaOAc}$ reagent caused the absorption maximum in methanol to shift $5 \mathrm{~m} \mu$ bathochromically. These data indicated the presence of phenolic hydroxy-groups at $\mathrm{C}-5$ and $\mathrm{C}-7 .{ }^{10}$ The remaining two phenolic hydroxy-groups have to be associated with the B-ring.

The pattern of $A B X$ system in the PMR spectra of Ia, Ib and Ic suggested the presence of a 2,4-dihydroxyphenyl residue in luteone. This was established by the degradation of luteone methyl ether (Ib) with alkaline hydrogen peroxide $;^{9,11)}$ this afforded 2,4-dimethoxybenzoic acid. Thus, luteone was found to be a $5,7,2^{\prime}, 4^{\prime}$-tetrahydroxy-isoflavone having a 3,3-dimethylallyl group. On the basis of evidence discussed above, the position of the 3,3-dimethylallyl group was restricted to either positions 6 or 8 .

Luteone was treated with a small amount of conc. sulfuric acid in acetic acid to yield two isomers called $\alpha$ - and $\beta$-isoluteone (IIa and IIIa, respectively). Both PMR spectra (pyridine- $\mathrm{d}_{5}$ ) of the isomers showed signals assignable to 2,2-dimethylchroman ${ }^{9,12)}(\alpha$ isoluteone: $6 \mathrm{H}$, s. at $\delta 1.47,2 \mathrm{H}, \mathrm{t} ., J=7 \mathrm{~Hz}$ at $\delta 1.80$ and $2 \mathrm{H}, \mathrm{t} ., J=7 \mathrm{~Hz}$ at $\delta 2.92, \beta$ isoluteone: $6 \mathrm{H}$, s. at $\delta 1.30,2 \mathrm{H}, \mathrm{t} ., J=7 \mathrm{~Hz}$ at $\delta 1.71$ and $2 \mathrm{H}$, t., $J=7 \mathrm{~Hz}$ at $\delta 2.73$ ). These data indicated that $\alpha$-and $\beta$-isoluteone were produced by an acid-catalized interaction of the 3,3dimethylallyl group and two appositely placed hydroxygroup (at $\mathrm{C}-5$ or $\mathrm{C}-7$ ). The decision between two possible structures for $\alpha$ - and $\beta$ isoluteone followed from the recognition that the PMR spectrum of the $\alpha$-isomer (IIa) showed no signal due to the chelated phenolic hydroxy-group, while that of the $\beta$-isomer (IIIa) exhibited the signal due to a hydroxygroup at $\mathrm{C}-5$. Methylation of $\alpha$ - and $\beta$ isomers with ethereal diazomethane afforded a trimethyl ether (IIb) and a dimethyl ether 
(IIIb) respectively, supporting the above assignment. Thus, the 3,3-dimethylallyl group was shown to be attached at C-6, and the structure Ia was assigned to luteone.

It is worthy of note that isoflavones having 2,4-dihydroxyphenyl residue as the B-ring are only auriculatin ${ }^{13)}$ and luteone among naturally-occurring isoflavones.

Some isoflavones have been known to have oestrogenic, insecticidal, piscicidal and antifungal activities. ${ }^{6,14)}$ The antifungal substances in red clover have been investigated and formonetin was characterized as the agent active against Sclerotinia trifoliorum and Fusarium nivale. ${ }^{15)}$

Table II. The Inhibitory EfFect of Luteone AND B-Isoluteone AGAINST THE CONIDIA OF Cochliobolus miyabeanus

\begin{tabular}{ccc}
\hline \multirow{2}{*}{$\begin{array}{c}\text { Concentration } \\
(\mu \mathrm{g} / \mathrm{ml})\end{array}$} & \multicolumn{2}{c}{ The conidial germination $(\%)$} \\
\cline { 2 - 3 } & Luteone & $\beta$-Isoluteone \\
\hline 1000 & 0 & 0 \\
500 & 0 & 63.6 \\
250 & 0 & 91.8 \\
125 & 0 & 97.2 \\
62.5 & 2.0 & 90.9 \\
31.25 & 3.5 & 96.5 \\
15.63 & 11.9 & 94.7 \\
7.81 & 59.3 & 95.0 \\
3.90 & 93.8 & 96.8 \\
1.95 & 95.0 & 95.8 \\
0 & \multicolumn{3}{c}{97.3} \\
\hline
\end{tabular}

The germination inhibitory effect of luteone against the conidia of Cochliobolus miyabeanus is shown in Table II. The half inhibition was obtained at a concentration of approximately $8 \mu \mathrm{g} / \mathrm{ml}$. $\beta$-Isoluteone had about one-fiftieth inhibitory activity of luteone. $\alpha$-Isoluteone was insoluble in solvents appropriate for biological studies.

The antimicrobial spectrum with 14 kinds of microorganisms is summarized in Table III. Luteone showed the activity against Staphylococcus aureus, Bacillus subtilis, Trichophyton mentagrophytes and T. rubrum. The piscicidal activity (TLm, $24 \mathrm{hr}$ ) of luteone was demonstrated against killifish (Oryzias laptipes) at a concentration of $3 \mu \mathrm{g} / \mathrm{ml}$. $\beta$-Isoluteone was inactive or less active than luteone in all bioassays tested.

\section{EXPERIMENTAL}

Melting points were determined on a hot stage, and are uncorrected. IR spectra were recorded on Hitachi EPI-G3 and were calibrated with the bands of polystyrene at $3027.1,1601.4$ and $906.7 \mathrm{~cm}^{-1}$ UV spectra were recorded with a Hitachi Perkin-Elmer EPS-3T spectrometer. Mass spectra were obtained with a Hitachi RMU-6D mass spectrometer (direct inlet system, $80 \mathrm{eV})$ and PMR spectra $(60 \mathrm{MHz})$ on a Hitachi R-20 spectrometer. Chemical shifts in the PMR spectra are expressed in ppm from tetramethyl silane as an internal standard and coupling constants in

Table III. Antimicrobial Spectrum of Luteone and $\beta$-Isoluteone

\begin{tabular}{|c|c|c|c|c|}
\hline \multirow{2}{*}{ Test organism } & \multicolumn{2}{|c|}{$\operatorname{MIC}(\mu \mathrm{g} / \mathrm{ml})$} & \multirow{2}{*}{ Method } & \multirow{2}{*}{ Medium } \\
\hline & Luteone & $\beta$-Isoluteone & & \\
\hline Aspergillus oryzae & $>200$ & $>200$ & Agar dilution method & Potato-sucrose \\
\hline Cochliobolus miyabeanus & $>200$ & $>200$ & " & " \\
\hline Fusarium oxysporum & $>200$ & $>200$ & $" \prime$ & $"$ \\
\hline Neurospora crassa & 200 & 200 & " & " \\
\hline Rhizoctonia solani & $>200$ & $>200$ & $"$ & " \\
\hline Trametes sanguineae & 200 & $>200$ & " & $"$ \\
\hline Saccharomyces cerevisiae & 200 & 200 & " & $" 1$ \\
\hline Bacillus subtilis & 100 & $>200$ & $"$ & Bouillon \\
\hline Escherichia coli & $>200$ & $>200$ & $"$ & $"$ \\
\hline Staphylococcus aurets & $\leq 25$ & $>200$ & " & " \\
\hline Chlorella ellipsoides & 200 & $>200$ & $"$ & Potato-sucrose \\
\hline Trichophyton rubrum & 10 & - & Dilution method & Sabouraud's \\
\hline " mentagrophytes & 10 & - & "l & " \\
\hline Candida ablicans & $>10$ & - & " & $"$ \\
\hline
\end{tabular}


$\mathrm{Hz}$. Singlet, doublet, triplet and multiplet are abbreviated to s., d., t., and m., respectively. Merck silica gel $G_{254}$ was used for thin-layer chromatography.

Bioassay: conidial germination test of Cochliobolus miyabeants. The conidia of $C$. miyabeants cultured on Czapek's medium at $28^{\circ} \mathrm{C}$ for $10 \sim 14$ days were used. The test was performed according to the procedure reported by $\mathrm{H}$. Asuyama et al. ${ }^{16}$

Antimicrobial spectrum. Fourteen microorganisms listed in Table III were used for the test. Agar dilution method and dilution method were performed according to the procedure presented by R. Yamamoto. ${ }^{17}$

Piscicidal test. The piscicidal test was carried out according to the procedure reported by K. Kawazu et al. ${ }^{181}$

Isolation of luteone. The isolation procedure was controlled by the inhibitory effect against the conidia of $C$. miyabeanus. Methanol extract obtained from the immature fruits $(60 \mathrm{~kg})$ of Lupinus luteus was concentrated under reduced pressure. The aqueous concentrate, after adjustment to $\mathrm{pH} 3$ with $6 \mathrm{~N} \mathrm{HCl}$, was shaken with benzene. The benzene extract $(120 \mathrm{~g})$ was chromatographed over silicic acid-Celite $(1: 2)$ by stepwise elution with benzene containing an increasing ratio $(5 \%)$ of ethyl acetate. Elution with $30 \%$ ethyl acetate in benzene gave a crude active material $(33 \mathrm{~g})$. Further chromatography on Florisil column by stepwise elution with benzene containing an increasing ratio $(5 \%)$ of ethyl acetate afforded a partially crystalline gum $(830 \mathrm{mg}, 15 \%$ ethyl acetate). Recrystallization from methanol-water gave luteone (550 mg) as pale yellow plates, mp $225 \sim 227^{\circ} \mathrm{C}$, (Found: $\mathrm{C}, 67.61 ; \mathrm{H}, 5.34$. Calcd. for $\mathrm{C}_{20} \mathrm{H}_{18} \mathrm{O}_{6}$ : $\mathrm{C}, 67.79 ; \mathrm{H}, 5.12 \%$, and recrystallization from methanol-ethyl acetate-water as pale yellow rods, mp 111 113 and $225 \sim 226^{\circ} \mathrm{C}$, (Found: C, 65.04; H, 6.02. Calcd. for $\mathrm{C}_{20} \mathrm{H}_{18} \mathrm{O}_{6} \cdot \mathrm{CH}_{3} \mathrm{COOC}_{2} \mathrm{H}_{5} ; \mathrm{C}, 65.15 ; \mathrm{H}$, $5.92 \%$ ), TLC (ethyl acetate: benzene, $1: 2$ ): a characteristic reddish purple spot $(R f 0.51)$ after spraying with $5 \%$ vanillin in conc. sulfuric acid, PMR ôms (DMSO$\left.\mathrm{d}_{\beta}\right)$ : 1.63 ( $3 \mathrm{H}$, br.s.), 1.73 (3H, br.s.), 3.24 ( $2 \mathrm{H}$, br.d., $J=8), 5.18(1 \mathrm{H}$, br.t., $J=8), 6.18 \sim 7.02(3 \mathrm{H}, \mathrm{ABX}$ system), 6.35 (1H, s.), 8.08 (1H, s.), 9.20 (1H, s.), 9.31 $(1 \mathrm{H}, \mathrm{s}), 10.78(1 \mathrm{H}, \mathrm{s})$ and $13.21(1 \mathrm{H}, \mathrm{s})$; (pyridine$\left.\mathrm{d}_{5}\right): 1.68$ ( $3 \mathrm{H}$, br.s.), 1.87 (3H, br.s.), $3.76(2 \mathrm{H}$, br.d., $J=8), 5.73(1 \mathrm{H}$, br.t., $J=8), 6.64(1 \mathrm{H}, \mathrm{s}),. 6.71 \sim 7.57$ (3H, ABX system), $8.22(1 \mathrm{H}, \mathrm{s}$ ) and $13.88(1 \mathrm{H}$, br. s.), IR $\nu_{\max }(\mathrm{Nujol}) \mathrm{cm}^{-1}: 3425,3300,3100 \mathrm{br} ., 1655$, $1620,1592,1557,1220,1063$ and 820 , Mass $m / e: 354$ $(\mathrm{M}+$ ), 339, 311 (base peak), 299, 281, 269, 241, 219, 205, 177 and 165 .
Luteone trimethyl ether $(\mathrm{Ib})$. A mixture of luteone $(70 \mathrm{mg})$, anhyd. potassium carbonate $(700 \mathrm{mg})$, dimethyl sulfate $(0.8 \mathrm{ml})$ and acetone $(30 \mathrm{ml})$ was heated under reflux for $36 \mathrm{hr}$. The bulk of the acetone was removed by distillation under reduced pressure and the residue was poured into water $(100 \mathrm{ml})$. Extraction with benzene and evaporation yielded an oil $(80 \mathrm{mg})$ which was crystallized from benzene-hexane, giving luteone trimethyl ether (Ib) (50 mg) as colorless needles, $\mathrm{mp}$ $136 \sim 137^{\circ} \mathrm{C}$, (Found: C, 69.68; H, 6.14. Calcd. for $\mathrm{C}_{23} \mathrm{H}_{24} \mathrm{O}_{6}: \mathrm{C}, 69.68 ; \mathrm{H}, 6.10 \%$ ), UV $\lambda_{\max } \operatorname{m} \mu: 265$ and $286 \mathrm{sh}$. (MeOH, = 25200 and 13200), 269 and $280 \mathrm{sh}$. $\left(\mathrm{AlCl}_{3}\right), 270$ and $281 \mathrm{sh} .(\mathrm{AlCl} / \mathrm{HCl}), \mathrm{PMR} \delta_{\mathrm{TMS}}$ $\left(\mathrm{CCl}_{4}\right): 1.65$ (3H, br.s.), 1.78 (3H, br.s.), $3.28(2 \mathrm{H}$, br.d., $J=8), 3.78$ (3H, s.), 3.80 (3H, s.), $3.89(3 \mathrm{H}$, s.), $5.15(1 \mathrm{H}$, br.t., $J=8), 6.29(1 \mathrm{H}$, s.), $6.35 \sim 7.22(3 \mathrm{H}$, ABX system), $7.72(1 \mathrm{H}, \mathrm{s}$.$) and 12.91(1 \mathrm{H}, \mathrm{s.}), \mathrm{IR} \nu_{\max }$ (Nujol) $\mathrm{cm}^{-1}: 3100,1660,1655,1620,1580$ and 1510 , Mass m/e: $396\left(\mathrm{M}^{+}\right), 381,365,353$ (base peak), and 341 .

Methylation of luteone with ethereal diazomethane yielded the same trimethyl ether (Ib).

Luteone tetraacetate (Ic). A mixture of luteone $(20 \mathrm{mg})$, pyridine $(1 \mathrm{ml})$ and acetic anhydride $(2 \mathrm{ml})$ was heated ( $5 \mathrm{hr}$ ) under reflux, cooled, poured into water $(40 \mathrm{ml})$, stirred $(2 \mathrm{hr})$ at room temp., and extracted with benzene. The benzene extract was washed with water, dried over anhyd. sodium sulfate and the solvent was removed to give an oil $(31 \mathrm{mg})$, which was purified by chromatography on silicic acid. Elution with benzene-ethyl acetate $(9: 1)$ gave luteone tetraacetate (Ic) as an intractable gum (25 mg), UV $\lambda_{\max }$ $\mathrm{m} \mu: 247$ and $309(\mathrm{MeOH}, \varepsilon 32000$ and 5300), PMR ótMs $\left(\mathrm{CCl}_{4}\right): 1.70$ (3H, br.s.), 1.72 (3H, br.s.), 2.04 ( $3 \mathrm{H}$, s.), 2.18 (3H, s.), 2.22 (3H, s.), 2.31 (3H, s.), 3.21 ( $2 \mathrm{H}$, br.d., $J=8$ ), 4.96 (1H, br.t., $J=8$ ), $6.95 \sim 7.20$ (3H, ABX system), $6.98(1 \mathrm{H}$, s.) and $7.68(1 \mathrm{H}, \mathrm{s.})$, IR $\nu_{\max }\left(\mathrm{CCl}_{4}\right) \mathrm{cm}^{-1}: 1780,1667,1620$ and 1190, Mass $m / e 522\left(\mathrm{M}^{+}\right), 481,439,426,395$ (base peak), 383 and 353.

Oxidation of luteone trimethyl ether $(\mathrm{Ib})$ : formation of 2,4-dimethoxybenzoic acid. Hydrogen peroxide $(30 \%$, w/v) was added dropwise in four portions $(1,1.5,1.5$ and $0.5 \mathrm{ml}$ ) at intervals of $1 \mathrm{hr}$ to a stirred solution of luteone trimethyl ether ( $\mathrm{Ib})(40 \mathrm{mg}$ ) in aqueous potassium hydroxide $(15 \%, 5 \mathrm{ml})$ and ethanol $(7 \mathrm{ml})$ at room temp. After $18 \mathrm{hr}$, the solution was concentrated under reduced pressure, acidified with $2 \mathrm{~N} \mathrm{HCl}$, and extracted with ether. The extract was shaken with aqueous sodium hydrogen carbonate $(10 \%)$, and the aqueous layer, after acidification, was re-extracted with ether to give acidic materials $(10 \mathrm{mg})$. Crystallization from ether gave an acid, mp $107 \sim 108^{\circ} \mathrm{C}$, which was identified as 2,4-dimethoxybenzoic acid by comparison (mixed mp and IR spectra) with an authentic 
sample. Alkaline hydrogen peroxide oxidation of luteone failed to afford 2,4-dihydroxybenzoic acid.

Acid-catalized transformation of luteone: formation of $\alpha$ - and $\beta$-isoluteone (IIa and IIIa). A mixture of luteone $(80 \mathrm{mg})$, gracial acetic acid $(1 \mathrm{ml})$ and conc. sulfuric acid $(0.1 \mathrm{ml})$ was heated at $100^{\circ} \mathrm{C}$ until solution occurred $(30 \mathrm{sec})$. The solution was left at room temp. $(36 \mathrm{hr})$, poured into water $(80 \mathrm{ml})$ and extracted with ethyl acetate. The ethyl acetate extract was chromatographed on silicic acid-Celite column by stepwise elution with benzene containing an increasing ratio $(5 \%)$ of ethyl acetate.

The eluate with $15 \%$ ethyl acetate was crystallized for benzene-hexane, giving $\beta$-isoluteone (IIIa) (19 mg) as pale yellow rods, $\mathrm{mp} 248 \sim 250^{\circ} \mathrm{C}$, (Found: $\mathrm{C}$, 68.01; H, 5.03. Calcd. for $\mathrm{C}_{20} \mathrm{H}_{18} \mathrm{O}_{6}: \mathrm{C}, 67.79 ; \mathrm{H}$, $5.12 \%$ ), UV $\lambda_{\max } \mathrm{m} \mu: 264$ and $288 \mathrm{sh}$. $(\mathrm{MeOH}, \varepsilon$ 29000 and 15100), 273 and $318\left(\mathrm{AlCl}_{3}\right), 275$ and 316 $\left(\mathrm{AlCl}_{3} / \mathrm{HCl}\right), 264$ and $289 \mathrm{sh}$. ( $\mathrm{NaOAc}$ ), and 264 and $289 \mathrm{sh} . \quad\left(\mathrm{NaOAc} / \mathrm{H}_{3} \mathrm{BO}_{3}\right)$, PMR $\delta_{\mathrm{TMS}}$ (pyridine-d $\left.\mathrm{d}_{5}\right)$ : $1.30(6 \mathrm{H}, \mathrm{s}),. 1.71(2 \mathrm{H}, \mathrm{t} ., J=7), 2.73(2 \mathrm{H}, \mathrm{t} ., J=7)$, 6.51 (1H, s.), $6.81 \sim 7.65(3 \mathrm{H}$, ABX system), 8.28 $(1 \mathrm{H}$, s. $)$ and $13.88(1 \mathrm{H}$, br.s. $), I R \nu_{\max }(\mathrm{Nujol}) \mathrm{cm}^{-1}$ : $3520,3390,3080,1660,1625,1602,1575$ and 1520 .

The eluate with $35 \%$ ethyl acetate was crystallized from acetone-water, giving $\alpha$-isoluteone (IIa) $(24 \mathrm{mg}$ ) as pale yellow prisms, $\mathrm{mp}>300^{\circ} \mathrm{C}$, (Found: $\mathrm{C}, 67.78$; $\mathrm{H}, 5.15$. Calcd. for $\mathrm{C}_{20} \mathrm{H}_{18} \mathrm{O}_{6}: \mathrm{C}, 67.79 ; \mathrm{H}, 5.12 \%$, UV $\lambda_{\max } \mathrm{m} \mu: 262$ and $288 \mathrm{sh}$. $(\mathrm{MeOH},=27500$ and $14400), 263$ and $289 \mathrm{sh}$. $\left(\mathrm{AlCl}_{3}\right), 263$ and $287 \mathrm{sh}$. $\left(\mathrm{AlCl}_{3} / \mathrm{HCl}\right), 271$ and $330 \mathrm{sh}$. (NaOAc), and 262 and $288 \mathrm{sh} . \quad\left(\mathrm{NaOAc} / \mathrm{H}_{3} \mathrm{BO}_{3}\right), \quad$ PMR $\delta_{\text {TMS }}$ (pyridine- $\mathrm{d}_{5}$ ): $1.47(6 \mathrm{H}, \mathrm{s}),. 1.80(2 \mathrm{H}, \mathrm{t} ., J=7), 2.92(2 \mathrm{H}, \mathrm{t} ., J=7)$, $6.68(1 \mathrm{H}, \mathrm{s}),. 6.78 \sim 7.45$ (3H, ABX system) and 8.08 $(1 \mathrm{H}, \mathrm{s}),. \mathrm{IR} \nu_{\max }(\mathrm{Nujol}) \mathrm{cm}^{-1}: 3280,3180,1625$ and 1550.

$\alpha$-Isoluteone trimethyl ether (IIb). Treatment of $\alpha$-isoluteone (IIa) (10 mg) with ethereal diazomethane gave a gum, which was crystallized from ether to yield $\alpha$-isoluteone trimethyl ether (IIb) $(10 \mathrm{mg})$ as colorless plates, mp $186 \sim 187^{\circ} \mathrm{C}$, UV $\lambda_{\text {max }} \mathrm{m} \mu: 254$ sh., 260 and 283 sh. (MeOH, 22600, 23800 and 10700), 254 sh., 261 and 283 sh. $\left(\mathrm{AlCl}_{3}\right)$, and $254 \mathrm{sh}$, 261 and $283 \mathrm{sh}$. $\left(\mathrm{AlCl}_{3} / \mathrm{HCl}\right)$, PMR ót $\left(\mathrm{CCl}_{4}\right): 1.40(6 \mathrm{H}, \mathrm{s}),$. $(2 \mathrm{H}, \mathrm{t} ., J=7), 2.60(2 \mathrm{H}, \mathrm{t} ., J=7), 3.77(3 \mathrm{H}, \mathrm{s}),$. $(3 \mathrm{H}, \mathrm{s}),. 3.86(3 \mathrm{H}, \mathrm{s}),. 6.23(1 \mathrm{H}, \mathrm{s}),. 6.32 \sim 7.21(3 \mathrm{H}$, ABX system) and $7.56(1 \mathrm{H}, \mathrm{s})$, IR $\nu_{\max }(\mathrm{Nujol}) \mathrm{cm}^{-1}$ : $1655,1635,1610 \mathrm{br}$. and 1580 , Mass m/e: $396\left(\mathrm{M}^{+}\right)$ and 365 .

$\beta$-Isoluteone dimethyl ether (IIIb). $\quad \beta$-Isoluteone (IIIa) $(15 \mathrm{mg}$ ) was methylated with ethereal diazomethane. Recrystallization from ether-hexane gave $\beta$-isoluteone dimethyl ether (IIIb) as pale yellow prisms, $\mathrm{mp} 151 \sim 152^{\circ} \mathrm{C}$, UV $\lambda_{\max } \mathrm{m} \mu: 263$ and $292 \mathrm{sh}$. (MeOH, $\varepsilon 24400$ and 10300$), 263$ and $300 \mathrm{sh}$. $\left(\mathrm{AlCl}_{3}\right)$, and 266 and $275 \mathrm{sh}$. $\left(\mathrm{AlCl}_{3} / \mathrm{HCl}\right), \mathrm{PMR} \delta_{\mathrm{TMS}}\left(\mathrm{CCl}_{4}\right): 1.35(6 \mathrm{H}$, s.), $1.80(2 \mathrm{H}, \mathrm{t} ., J=7), 2.69(2 \mathrm{H}, \mathrm{t} ., J=7), 3.77(3 \mathrm{H}, \mathrm{s}$.$) ,$ 3.80 (3H, s.), $6.20(1 \mathrm{H}, \mathrm{s}),. 6.35 \sim 7.22(3 \mathrm{H}, \mathrm{ABX}$ system), $7.69\left(1 \mathrm{H}\right.$, s.) and $13.10\left(1 \mathrm{H}\right.$, s.), $\operatorname{IR} \nu_{\max }$ (Nujol) $\mathrm{cm}^{-1}: 3070,1665 \sim 1655,1620,1610$ and 1590 , Mass $m / e: 382\left(\mathrm{M}^{+}\right)$and 351 .

Acknowledgement. We wish to thank Dr. Akira Kato, College of Pharmacy, Kyoto University, for the measurements of mass spectra.

\section{REFERENCES}

1) K. Koshimizu, H. Fukui, T. Kusaki, Y. Ogawa and T. Mitsui, Agr. Biol. Chem., 32, 1135 (1968).

2) H. Fukui, H. Ishii, K. Koshimizu, M. Katsumi, Y. Ogawa and T. Mitsui, ibid., 36, 1003 (1972).

3) H. Fukui, K. Koshimizu and T. Mitsui, Phytochemistry, 10, 671 (1971).

4) K. Koshimizu, H. Fukui, T. Mitsui and Y. Ogawa, Agr. Biol. Chem, 30, 941 (1966).

5) K. Koshimizu, M. Inui, H. Fukui and T. Mitsui, ibid., 32, 789 (1968).

6) W. D. Ollis, "The Chemistry of the Flavonoid Compounds," ed. by T. A. Geissman, Pergamon Press, Oxford, 1962, p. 353.

7) L. Jurd, "The Chemistry of the Flavonoid Compounds," ed. by T. A. Geissman, Pergamon Press, Oxford, 1962, p. 107.

8) C. P. Falshaw, W. D. Ollis, J. A. Moore and K. Magnus, Tetrahedron, suppl., 7, 333 (1966).

9) J. S. P. Schwarz, A. I. Cohen, W. D. Ollis, E. A. Kaczka and L. M. Jackman, ibid., 20, 1317 (1964).

10) T. J. Mabry, K. R. Markham and M. B. Thomas, "The Systematic Identification of Flavonids," Springer-Verlag, Berlin, 1970, p. 165.

11) W. D. Ollis, C. A. Rhodes and I. O. Sutherland, Tetrahedron, 23, 4741 (1967).

12) A. J. East, W. D. Ollis and R. E. Wheeler, J. Chem. Soc. (C), 1969, 365.

13) M. Schabbir, A. Zaman, L. Crombie, B. Tuck and D. A. Whiting, ibid., 1899 (1968).

14) F. M. Dean, "Naturally Occurring Oxygen Ring Compounds," Butterworths, London, 1963 , p. 366.

15) A.I. Virtanen and P. K. Hietala, Acta Chem. Scand., 12, 579 (1958).

16) H. Asuyama, H. Muko and N. Suzuki, "Laboratory Guide for Plant Pathologists," Japan Plant Protection Association, Tokyo, 1962, p. 675 .

17) R. Yamamoto, "Shin-noyaku-kenkyuho," Nankodo, Tokyo, 1958, p. 363.

18) K. Kawazu, M. Inaba and T. Mitsui, Agr. Biol. Chem., 31, 494 (1967). 